\title{
A Survey of Puerto Rican Soils for Entomogenous Nematodes Which Attack Diaprepes abbreviatus (L.) (Coleoptera:Curculionidae) $)^{1,2}$
}

\author{
J. Román and J. B. Beavers ${ }^{3}$
}

\begin{abstract}
A survey was conducted to determine the presence of entomogenous nematodes which might parasitize Diaprepes abbreviatus (L.) larvae in Puerto Rican soils. One larva (2.3\%) was parasitized with Heterorhabditis sp. Poinar when 4-month-old larvae were placed in the soil at eight different sites throughout the Island. Soil samples, taken from sugarcane fields and pasture lands in five geographical regions during July and September 1980, and January and April 1981, and inoculated with $D$. abbreviatus larvae did not reveal entomogenous nematodes. In the laboratory, when Neoaplectana carpocapsae Weiser was introduced into sterile soil from these regions, $40 \%$ of the exposed $D$. abbreviatus larvae became infected. We believe this is the first: report of the entomogenous nematode, Heterorhabditis sp., occurring in Puerto Rico.
\end{abstract}

\section{INTRODUCTION}

Diaprepes abbreviatus (L.), the so-called surgarcane rootstalk borer weevil or "vaquita," is now considered to be the most important pest of sugarcane in Puerto Rico (7); other cultivated host plants such as Citrus sp. and pigeon pea, Cajanus indicus, are also seriously attacked. The weevil eggs are deposited in masses between sugarcane blades. Hatchling larvae drop to the ground where they feed on the root systems during their younger larval stages, and as they mature, they bore into the subterranean portions of the cane stems. In heavily infested areas, portions of newly planted sugarcane fields are destroyed; late replanting is necessary. In addition, maturing cane stools dry and brown early; the result is premature harvest or death of the plant. The adult weevils emerge after 1-2 years (8). In 1979-80, the gross income from sugarcane production in Puerto Rico was $\$ 56$ million (3), an amount which represents an important role in the Island's economy. Although the total land devoted to sugarcane production is currently being reduced, attempts are being made to increase yields by intensifying production technology (6).

${ }^{1}$ Submitted to Editorial Board August 9, 82.

${ }^{2}$ Joint Contribution from the Horticultural Research Laboratory, USDA, ARS, Orlando, FL, and the Agricultural Experiment Station, University of Puerto Rico, Mayaguez Campus, Rio Piedras, PR.

${ }^{3}$ Nematologist, Agricultural Experiment Station, University of Puerto Rico, Mayagüez Campus, and Research Entomologist, Horticultural Research Laboratory, USDA, ARS, Orlando, FL, respectively. The authors wish to thank Dr. G. O. Poinar, Jr., University of California, Berkeley, and Dr. D. T. Kaplan, USDA, ARS, Orlando, Florida, for assistance in nematode identification. 
An important aspect in this effort is to develop new control techniques for $D$. abbreviatus, since losses attributed to this insect during 1978-79 were estimated to be $\$ 27.7$ million (4). So far, no new insecticides evaluated since aldrin was removed from the market have proved to be effective in controlling this insect.

In a recent 2-year study to determine the natural enemies attacking the subterranean stages of $D$. abbreviatus in Florida (2), the entomogenous nematodes, Heterorhabditis sp. Poinar (probably H. heliothidis) and Neoaplectana carpocapsae Weiser were found to be the primary parasites recovered when $D$. abbreviatus larvae were introduced into the soil. The results of their study indicated that the parasitization rate was high from May through November, peaking at $70 \%$ in July 1980. D. abbreviatus larvae were inoculated into soil samples taken from 55 groves located throughout Florida's citrus growing region; in $47 \%$ of the groves either Heterorhabditis sp. and/or Neoaplectana sp were present.

Since these entomogenous nematodes are not known to occur in Puerto Rico but are widespread in Florida and show potential for biological control of D. abbreviatus, we conducted a soil survey in Puerto Rico to determine whether nematode parasites of $D$. abbreviatus larvae were present.

\section{MATERIALS AND METHODS}

Two survey techniques were used. In the first, 10 laboratory-reared 4month-old $D$. abbreviatus larvae (1) obtained from the USDA Citrus Root Weevil Laboratory, Orlando, Florida, were caged in individual 7.5 $\times 12.5 \mathrm{~cm}$ wirescreen cages $\left(324 \mathrm{mesh} / \mathrm{cm}^{2}\right)$ and placed $30 \mathrm{~cm}$ deep in sugarcane fields at eight locations October 29, 1979 (fig. 1a). The cages were recovered after 2 weeks and the larvae examined for nematode infection. In the second test, soil samples were collected from sugarcane fields and pasturelands in five geographical zones of Puerto Rico: north, south, east, west and central (fig. 1b). Samples were taken from five areas within each geographic zone and brought to the laboratory. Soil samples were taken at each site at four different times: July and September 1980, and January and April 1981. Samples were analyzed for $\mathrm{pH}$ and for percent sand, clay, and silt content. In the laboratory, each sample was thoroughly mixed and placed in 1-kg aliquots in cylindrical cardboard containers with three replications. These were inoculated with five $D$. abbreviatus larvae (375 larvae/test) and stored at $23-26^{\circ} \mathrm{C}$ for 2 to 3 weeks. The soil was adequately moistened throughout the duration of each test. At the end of the incubation period, each sample was carefully screened and larvae examined. All larvae recovered were cut into 2 or 3 pieces, and placed on a 10-mesh screen on top of Baermann funnels filled 
with water. After 12 hours, $10 \mathrm{ml}$ of water were drained from the funnels and examined for nematodes.

In a third test to determine whether $N$. carpocapsae was capable of parasitizing D. abbreviatus larvae in Puerto Rican soil types, three 1-kg soil samples taken from each of the five geographical zones were steam sterilized, we infested the soil samples with $N$. carpocapsae by placing five nematode-infected bait crickets containing about 375,000 nematodes and four or five $D$. abbreviatus larvae into each container. After an incubation period of 2 weeks, larvae were removed from the soil, placed
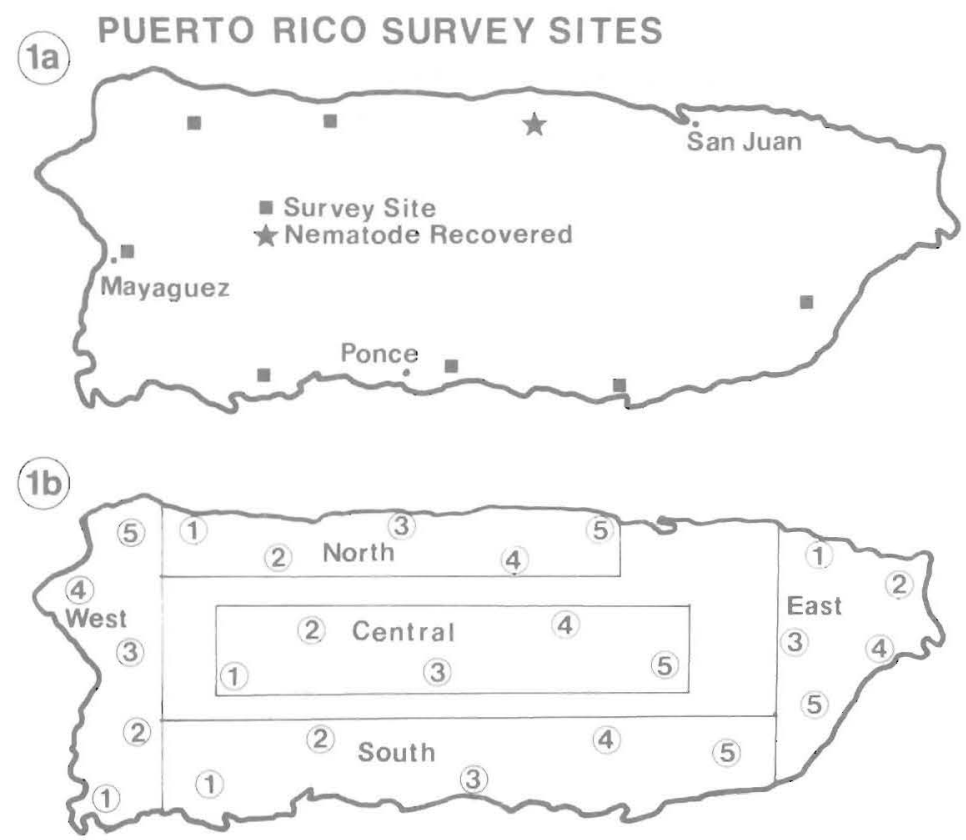

FIG. 1a.-Survey sites for Diaprepes abbreviatus larvae placed in individual screen cages. Ten larvae/site. 1b.- Soil sampling sites for laboratory bioassay to determine presence of entomogenous nematodes.

in individual petri dishes on filter paper moistened with a $0.25 \mathrm{NaCl}$ solution, and held to determine nematode emergence.

\section{RESULTS AND DISCUSSION}

In the first test, when $D$. abbreviatus larvae were placed in individual screen cages, of the 46 larvae recovered ( 35 alive, 11 dead), one larva $(2.3 \%)$ recovered from a sugarcane field approximately $15 \mathrm{~km}$ west of 
San Juan was infected with Heterorhabditis sp. (fig. 1a). No Neoaplectana sp. were recovered in this test.

In the second test, when soil samples were infested with $D$. abbreviatus larvae in the laboratory, none of the 1,500 larvae exposed during the 4 sampling periods became infected by either nematode species. Of the total larvae exposed, $67.6 \%$ were recovered alive without nematodes, $14.6 \%$ were not recovered, probably because of disintegration after death; $7.5 \%$ were dead without nematodes; and $10.3 \%$ were dead and associated with a number of nematode genera not considered to be entomogenous. These were Cephalobus sp., Aphelenchus sp., and Dorylaimus sp., as well as rhabditids and diplogasterids.

TABLE 1.-Infection of Diaprepes abbreviatus larvae by Neoaplectana carpocapsae in soil types from five geographic regions in Puerto Rico

\begin{tabular}{|c|c|c|c|c|c|c|}
\hline Loc & ation & $\begin{array}{l}\text { Living } \\
\text { nonin- } \\
\text { fected } \\
\text { larvae }\end{array}$ & $\begin{array}{l}\text { N. carpocapsae } \\
\text { infected larvae }\end{array}$ & $\begin{array}{c}\text { Dead } \\
\text { non-in- } \\
\text { fected }\end{array}$ & $\begin{array}{l}\text { Not } \\
\text { recovered }\end{array}$ & Total \\
\hline \multirow[t]{3}{*}{ East } & 1 & 1 & 0 & 3 & 0 & 4 \\
\hline & 2 & 2 & 1 & 1 & 0 & 4 \\
\hline & $3^{1}$ & 2 & 1 & 1 & 1 & 5 \\
\hline \multirow[t]{3}{*}{ Central } & 1 & 0 & 1 & 2 & 1 & 4 \\
\hline & 2 & 1 & 0 & 3 & 0 & 4 \\
\hline & $3^{1}$ & 1 & 3 & 0 & 1 & 5 \\
\hline \multirow[t]{3}{*}{ West } & 1 & 0 & 1 & 3 & 0 & 4 \\
\hline & 2 & 3 & 1 & 0 & 0 & 4 \\
\hline & $3^{1}$ & 2 & 1 & 2 & 0 & 5 \\
\hline \multirow[t]{3}{*}{ North } & 1 & 0 & 3 & 1 & 0 & 4 \\
\hline & 2 & 0 & 2 & 2 & 0 & 4 \\
\hline & $3^{1}$ & 1 & 2 & 2 & 0 & 5 \\
\hline \multirow[t]{4}{*}{ South } & 1. & 1 & 3 & 0 & 0 & 4 \\
\hline & 2 & 1 & 3 & 0 & 0 & 4 \\
\hline & $3^{1}$ & 0 & 4 & 1 & 0 & 5 \\
\hline & & $\overline{15}$ & $\overline{26}$ & 21 & 3 & $\overline{65}$ \\
\hline
\end{tabular}

${ }^{1}$ Inoculated with five $D$. abbreviatus larvae; all others with four.

In the test to determine whether $N$. carpocapsae could infect $D$. abbreviatus larvae in the Puerto Rican soil types, $40.0 \%$ infection was obtained from the 65 larvae exposed (table 1). Infection was obtained in all soil samples except one sample in the eastern and one in the central regions. The greatest infection rate $(76.9 \%)$ occurred in soils from the southern region, where high populations of $D$. abbreviatus occur.

The soil samples from both regions were highly variable sand (37.8 to $79.8 \%$ ), clay (12.1 to $30.7 \%$ ), and silt ( 8.0 to $37.4 \%$ ) content; however, the samples from the southern region were of a more uniform sandy texture. The $\mathrm{pH}$ of the soil samples ranged from 3.5 to 7.9 and appeared 
to have no effect on the ability of $N$. carpocapsae to parasitize the $D$. abbreviatus larvae in the laboratory study.

Although Heterorhabditis sp. was recovered from one D. abbreviatus larvae placed in the soil, no additional parasitism was found in the 4 subsequent soil samplings. Neoaplectana carpocapsae was not detected by either sampling technique; however, it was found to be capable of parasitizing $D$. abbreviatus in the various soil types in the laboratory.

The findings of this study indicate that the natural entomogenous nematode population is very low. This could be due to several factors, such as natural predation by fungi and mites, to toxicity of previously used nematicides, or the Heterorhabditis sp. recovered may be a recent introduction with limited ability to disperse. Although little is known about the distribution and occurrence of entomogenous nematodes in insular areas, we believe this is the first report of the occurrence of Heterorhabditis sp. in Puerto Rico. Since these entomogenous nematodes are known to have a broad host range (5), and soil is their natural habitat, once established they may become self-perpetuating natural enemies of D. abbreviatus. This potential, combined with the recent development of commercial production techniques for these nematodes, justifies further investigation of these organisms for possible biological control of $D$. abbreviatus in Puerto Rico.

\section{RESUMEN}

Un reconocimiento para determinar la presencia de nematodos entomófagos que podrian parasitar larvas de la vaquita de la caña de azúcar, Diaprepes abbreviatus (L.), se efectuó en diferentes suelos de Puerto Rico. Una larva (2.3\%) fue parasitada per Heterorhabditis sp. Poinar cuando se colocaron larvas de 4 meses en el suelo en ocho sitios diferentes de la Isla. Muestras de suelo, tomadas de cañaverales y pastizales en cinco zonas geográficas durante julio y septiembre de 1980 y enero y abril de 1981 e inoculadas con larvas de D. abbreviatus, no indicaron la presencia de nematodos entomófagos. Cuando Neoaplectana carpocapsae Weiser se introdujo en suelo esterilizado a vapor de las diferentes zonas, bajo condiciones de laboratorio, $40 \%$ de las larvas de D. abbreviatus fueron infectadas. Este parece ser el primer informe de la presencia de Heterorhabditis sp. en Puerto Rico. Estudios adicionales sobre el posible uso de estos nematodos en el control biológico de D. abbreviatus en Puerto Rico deben ser efectuados.

\section{LITERATURE CITED}

1. Beavers, J. B., 1982. Biology of Diaprepes abbreviatus (Coleoptera: Curculionidae) reared on an artificial diet, Fla. Entomol. 65: 263-69.

2. — C. W. McCoy and D. T. Kaplan, 1982. Natural enemies of Diaprepes abbreviatus 


\section{JOURNAL OF AGRICULTURE OF UNIVERSITY OF PUERTO RICO}

larvae in central Florida, Environ. Entomol. (In press.)

3. Departamento de Agricultura de Puerto Rico, Oficina de Estadísticas Agricolas, 1981. Ingreso Agrícola de Puerto Rico 1978-79-1979-80, pág. 3.

4. Estacion Experimental Agrícola, Univ. de P. Rico, 1979. Informe Anual 1978-79, pág. 4.

5. Poinar, Jr., G. O., 1975. Entomogenous nematodes, Leiden, The Netherlands, E. J. Brill.

6. Vincente-Chandler, J. (Ed), 1978. Conceptos, plan y programa para una agricultura moderna en Puerto Rico, Esta. Exp. Agric. Univ. P. R.

7. Wolcott, G. N., 1948. The insects of Puerto Rico, J. Agric. Univ. P.R. 32 (1-4): 975.

8. — 1936. The life history of Diaprepes abbreviatus at Rio Piedras. J. Agric. Univ. P.R. 20: 883-914. 